Georgetown University Law Center

Scholarship @ GEORGETOWN LAW

2020

Science, Leadership, and Public Trust in the COVID-19 Pandemic

Lawrence O. Gostin

Georgetown University - Law Center - O'Neill Institute for National and Global Health Law,

gostin@law.georgetown.edu

This paper can be downloaded free of charge from:

https://scholarship.law.georgetown.edu/facpub/2308

https://ssrn.com/abstract=3705602

Science, Leadership, and Public Trust in the COVID-19 Pandemic. Milbank Quarterly Opinion. September 28, 2020.

This open-access article is brought to you by the Georgetown Law Library. Posted with permission of the author. Follow this and additional works at: https://scholarship.law.georgetown.edu/facpub

Part of the Health Law and Policy Commons, and the International Humanitarian Law Commons 


\section{Science, Leadership, and Public Trust in the COVID-19 Pandemic}

https://www.milbank.org/quarterly/opinions/science-leadership-and-public-trust-in-the-covid-19pandemic/

A novel, unidentified virus in Wuhan, China, ignited a historic global pandemic within months. Nature and human behavior combined to produce a global crisis, but our singular tool to curb COVID-19 is science. And, yet, scientific agencies in the United States are under threat as never before.

The COVID-19 pandemic has ushered in a new golden age of scientific discovery. Within weeks of the first reported cases, Chinese scientists had sequenced the entire viral genome. Epidemiologists identified respiratory droplets as the primary transmission mode and recommended interventions such as handwashing, social distancing, and face coverings. The Randomized Evaluation of COVID-19 Therapy (RECOVERY) trial demonstrated the effectiveness of dexamethasone for seriously ill patients. Meanwhile, other promising therapies are under investigation, including convalescent plasma, monoclonal antibodies, and antivirals. Remdesivir, for example, is an antiviral approved for emergency use. As of September 17, there were 92 preclinical vaccines and 40 vaccines in human trials, including 9 vaccines in Phase 3 large-scale placebo-controlled trials.

Yet, scientific understanding is only as powerful as society's confidence in scientific expertise and the public's willingness to adhere to its findings. If I were to identify a single reason some countries have performed well in containing COVID-19, it would be the adherence to science in health messaging and public policies. By this measure, the United States is among the world's worst, even though the Global Health Security Index (GHSI) ranked the nation first in pandemic preparedness in 2019. Clearly, leadership matters.

\section{US Leadership Sidelines Science}

In his book Rage, Bob Woodward reveals that President Trump was informed in late January that COVID-19 would be the nation's gravest security threat. Yet, the president told the public the novel coronavirus was "no worse than seasonal flu" and would "disappear" seasonally. In late February, the White House required all government scientists to clear health messages with Vice President Pence. As a result, the Centers for Disease Control and Prevention (CDC) paused media statements, while senior career scientist Dr. Nancy Messonnier was removed from White House briefings after forecasting an exponential rise in COVID-19 cases. President Trump publicly criticized Dr. Anthony Fauci for repeated "mistakes" after the National Institutes of Health scientist countered the president's claim the virus would disappear.

In every previous public health crisis, the CDC has issued scientific guidelines for prevention and control, without political vetting or interference. However, in April, the Trump administration blocked CDC guidelines for reopening schools and businesses, labeling them 
“overly prescriptive." In July, the president critiqued CDC school-reopening guidelines and demanded that the agency reissue its guidance. That same month, the Department of Health and Human Services (HHS) ordered hospitals to bypass the CDC and report data directly to a HHS private vendor. Facing added pressure in August, the $\mathrm{CDC}$ relaxed testing guidelines, recommending against clinical testing of asymptomatic persons who came in close contact with an infected person, which independent scientists widely criticized. The New York Times now reports that the CDC's testing guidance was published over the objections of career CDC scientists. If true, these testing guidelines have been misleading the public, who have a right to assume the agency's recommendations are based on objective scientific assessments. On September 18, the agency changed its testing guidelines again, this time urging testing of asymptomatic contacts.

The Trump administration has put the CDC in the middle of partisan politics. In recommending strong, evidence-based measures against COVID-19, the agency risks being further sidelined. But, by appealing to the Trump administration's desire for more lenient guidelines, the agency will lose credibility and public trust when the guidelines prove insufficient to protect against viral spread.

By September $16^{\text {th }}$, when US COVID-19 cases reached 6.6 million, with nearly 200,000 deaths, President Trump demeaned CDC Director Robert Redfield, saying his Congressional testimony was "incorrect," "mistaken," and "confused." Dr. Redfield's testimony, however, was consistent with scientific assessments - masks were highly effective, and a vaccine would not be widely available until the $2^{\text {nd }}$ or $3^{\text {rd }}$ quarter of 2021. Earlier, the CDC had subtly capitulated to White House messaging on Operation Warp Speed, asking states to be ready to distribute a vaccine by late October, just before the presidential election.

Above all, the CDC is a scientific agency, using its flagship peer-reviewed journal Morbidity and Mortality Weekly Report (MMWR) to report outbreaks and transmission patterns, while publishing cutting-edge research on prevention. Recall $M M W R$ 's groundbreaking report nearly forty years ago of five cases of pneumocystis carinii pneumonia among previously healthy young men. During the Reagan and Bush administrations, the CDC continued to publish scientific research and guidance on HIV prevention. Yet, HHS today has been requiring the CDC to allow advance review of peer-reviewed coronavirus publications, saying the agency's reports would undermine President Trump's optimistic messages on the pandemic.

The Food and Drug Administration (FDA) has fared little better. The FDA is charged with ensuring the safety and effectiveness of drugs and vaccines, with science as its sole guide. In March, the FDA issued an emergency use authorization (EUA) for hydroxychloroquine to treat COVID-19, after President Trump heavily promoted the drug. The FDA later revoked its EUA given evidence that hydroxychloroquine was associated with severe cardiac and other adverse events in COVID-19 patients. In April, the president said injecting disinfectants, such as bleach, could rid the body of the virus. Industry had to issue hazard warnings against drinking or injecting their cleaning products. In August, the FDA granted an EUA for convalescent plasma, even though NIH scientists publicly argued there were insufficient data. These actions call into question the strength of evidence, and process for decision-making, to treat patients during a 
pandemic. On September $15^{\text {th }}$, HHS Secretary Alex Azar barred FDA and other health agencies from signing any new rules regarding the nation's foods, medicines, vaccines, and medical devices - a sweeping blow to the agency's independence and authority.

Perhaps most important is the political urgency swirling around an EUA or full FDA approval of a COVID-19 vaccine before the completion of Phase 3 clinical trials. Thus far, Russia and China have issued an EUA for their respective vaccines, while the United Arab Emirates granted emergency use for the Chinese vaccine. What separates the United States from these undemocratic nations is its tradition of institutional guardrails, in the form of a robust and independent FDA. In response to political pressure to fast-track a vaccine before the election, the FDA center directors affirmed fidelity to science and pledged not to rush COVID-19 vaccine development. At the same time, nine pharmaceutical companies issued a joint pledge to "stand with science" and not put forward a vaccine candidate without rigorous data on safety and effectiveness. It is remarkable that a renowned scientific agency and for-profit pharmaceutical firms both felt obliged to pledge loyalty to science. That is how politicized science has become in this administration.

A COVID-19 vaccine may be the most coveted medical resource in generations. Yet it is unlikely to achieve herd immunity unless it has a high rate of effectiveness $(>50 \%)$ and wide public acceptance $(>70 \%)$. Perceptions of political interference in regulatory approval generate distrust, while amplifying fears about a future vaccine's safety and effectiveness. In early August, a Gallup Poll reported that $35 \%$ of Americans would not seek a free, FDA-approved vaccine. By September 10, a Kaiser Family Foundation poll found that $54 \%$ of respondents would not get vaccinated if the FDA approved a vaccine before election day. Vaccine hesitancy among black Americans, hardest hit by COVID-19, is consistently higher than for white Americans.

Globally, the Trump administration has also attacked scientific agencies and critical COVID-19 initiatives. The World Health Organization's Constitution was signed in New York on July 22, 1946, entering into force on April 7, 1948. The United States has been the Organization's largest donor, with our public health agencies embedded in WHO. Yet, on July 7, President Trump gave the United Nations Secretary General one year's notice of his intention to withdraw the US from the Organization. Since then, the president has unlawfully withheld Congressionally appropriated funds.

The president has also announced that the US will not join the COVID-19 Vaccine Global Access (COVAX) Facility, a global partnership that aims to support the development of a vaccine and share access to it. The expressed reason for not joining is that COVAX is co-led by WHO, along with Gavi (the Vaccine Alliance) and the Coalition for Epidemic Preparedness Innovations (CEPI). In essence, the president is betting that a US vaccine will be first and best. He is right to invest in US vaccines, but by also joining COVAX, we would have more reliable access to other approved vaccines. Of the nine Phase 3 trials of vaccine candidates, four are 
Chinese vaccines and a fifth includes a Chinese manufacturer as part of a three-company collaboration.

Science and security globally are at stake as well. And, if COVID-19 is spreading widely in any part of the globe, it will ultimately impact the health and safety of Americans.

\section{Science at the Forefront}

Science does not always tell us what we want to hear. During a pandemic, following the science may lead to business closures and unemployment, not being able to visit family and friends, or cancelling travel plans. But, we won't exit this pandemic without political leaders backing sound science. The public must be able to access information from scientific agencies like the CDC and FDA, and trust in their guidance without questioning their motive. Science gives humanity a fighting chance against Mother Nature. We must wield it carefully, wisely, and wholly.

Acknowledgements: I thank Sarah Wetter and Eric Friedman of the O'Neill Institute for National and Global Health Law, Georgetown University, for their invaluable support. 